\title{
Decreased Thrombospondin-1 and Bone Morphogenetic Protein-4 Serum Levels as Potential Indices of Advanced Stage Lung Cancer
}

\author{
Monika Kosacka ${ }^{1, *}$, Tomasz Dyła ${ }^{1}$, Monika Chaszczewska-Markowska ${ }^{2}$, Katarzyna Bogunia-Kubik ${ }^{2}$ and \\ Anna Brzecka ${ }^{1}$ (D) \\ 1 Department of Pulmonology and Lung Oncology, Wroclaw Medical University, 53439 Wroclaw, Poland; \\ tomasz.dyla@umed.wroc.pl (T.D.); anna.brzecka@umed.wroc.pl (A.B.) \\ 2 Laboratory of Clinical Immunogenetics and Pharmacogenetics, Ludwik Hirszfeld Institute of Immunology \\ and Experimental Therapy, Polish Academy of Sciences, 53114 Wroclaw, Poland; \\ monika.chaszczewska-markowska@hirszfeld.pl (M.C.-M.); katarzyna.bogunia-kubik@hirszfeld.pl (K.B.-K.) \\ * Correspondence: monika.kosacka@umed.wroc.pl; Tel.: +48-71-334-9559; Fax: +48-71-334-9596
}

check for

updates

Citation: Kosacka, M.; Dyła, T.; Chaszczewska-Markowska, M.;

Bogunia-Kubik, K.; Brzecka, A. Decreased Thrombospondin-1 and Bone Morphogenetic Protein-4 Serum Levels as Potential Indices of Advanced Stage Lung Cancer. J. Clin. Med. 2021, 10, 3859. https://doi.org/ $10.3390 /$ jcm10173859

Academic Editor: Ramon

Andrade De Mello

Received: 15 July 2021

Accepted: 24 August 2021

Published: 27 August 2021

Publisher's Note: MDPI stays neutral with regard to jurisdictional claims in published maps and institutional affiliations.

Copyright: () 2021 by the authors Licensee MDPI, Basel, Switzerland. This article is an open access article distributed under the terms and conditions of the Creative Commons Attribution (CC BY) license (https:// creativecommons.org/licenses/by/ $4.0 /)$

\begin{abstract}
Introduction: Lung cancer belongs to the most common carcinoma worldwide and is the leading cause of cancer-related death. Bone morphogenetic protein-4 (BMP-4) is extracellular signaling molecule involved in many important processes, including cell proliferation and mobility, apoptosis and angiogenesis. Thrombospondin-1 (TSP-1) belongs to the extracellular matrix proteins. It participates in the cell-to-cell and cell-to-matrix interactions and thus plays important role in tumor microenvironment for cancer development and metastasis formation. Aim: To investigate serum levels of TSP-1 and BMP-4 together with BMP-4 polymorphism in lung cancer patients. Material and Methods: A total of 111 patients (76 men) with newly diagnosed lung cancer, including 102 patients with non-small cell lung cancer and 9 patients with small-cell lung cancer. Advanced stage of lung cancer was diagnosed in 99 (89\%) of patients: stage IV—in 48, stage IIIB-in 33, stage IIIA—in 18 patients; there were six patients with stage II and six patients with stage I. The control group consisted of 61 healthy persons. In all the subjects, serum levels of BMP-4 and TSP-1 were measured by ELISA. With a Real-Time PCR system genotyping of BMP-4 was performed. Results: BMP-4 and TSP-1 serum levels were significantly lower in the patients with lung cancer than in the controls (TSP-1:10,109.2 $\pm 9581 \mathrm{ng} / \mathrm{mL}$ vs. 11,415.09 $\pm 9781 \mathrm{ng} / \mathrm{mL}, p<0.05 ;$ BMP-4: $138.35 \pm 62.59 \mathrm{pg} / \mathrm{mL}$ vs. $226.68 \pm 135.86 \mathrm{pg} / \mathrm{mL} p<0.001)$. In lung cancer patients TSP-1 levels were lower in advanced stages $(9282.07 \pm 4900.78 \mathrm{ng} / \mathrm{mL}$ in the stages III-IV vs. $16,933.60 \pm 6299.02 \mathrm{ng} / \mathrm{mL}$ in the stages I-II, $p<0.05)$ and in the patients with than without lymph nodes involvement $(10,000.13 \pm 9021.41 \mathrm{ng} / \mathrm{mL}$ vs. $18,497.75 \pm 12,548.25 \mathrm{ng} / \mathrm{mL}, p=0.01$ ). There was no correlation between TSP-1 and BMP-4 serum levels. BMP-4 gene polymorphism did not influence the results of the study. Conclusion: Decreased levels of TSP-1 and BMP-4 may serve as potential indices of lung cancer, with additional importance of low TSP-1 level as a marker of advanced stage of the disease.
\end{abstract}

Keywords: lung cancer; biomarkers; thrombospondin-1; bone morphogenetic protein-4

\section{Introduction}

Lung cancer belongs to the most common carcinoma worldwide. It is the leading cause of cancer-related death in both genders [1,2]. Despite modern diagnostic techniques and new treatment options, the long-term survival only improved a little and prognosis still remains poor [3]. There are some known lung cancer biomarkers such as epidermal growth factor receptor (EGFR) mutations, anaplastic lymphoma kinase, ROS gene rearrangements or immunohistochemical expression of programmed death-ligand 1 (PD-L1) that significantly influenced clinical practice [4-6]. Better understanding of carcinogenesis and identification of some other biomarkers could have diagnostic and/or prognostic 
value. That is why a search of a new promising biomarkers plays important role in lung cancer diagnosis and monitoring. There are some laboratory and clinical data that may indicate that two other particles may join to still elongating list of biomarkers in the lung cancer patients. These are thrombospondin-1 (TSP-1) and bone morphogenetic protein-4 (BMP-4).

TSP-1 belongs to thrombospondins family, which consists of five homologous members TSP-1, TSP-2, TSP-3, TSP-4 and TSP-5 [7]. TSP-1, a filamentous glycoprotein $\sim 70 \mathrm{~nm}$ long, is encoded by the THBS1 gene in human [8] and has homotrimeric form [9]. TSP-1 is produced by many different cell types, including thrombin-stimulated platelets and endothelial cells [10]. This protein participates in the cell-to-cell and cell-to-matrix interactions and thus plays important role in tumor microenvironment for cancer development and metastasis formation [11]. Solid tumors consist not only of active proliferating carcinoma cells but also of other cell types that create the proper microenvironment promoting tumor progression [12]. TSP-1 in the tumor microenvironment influences the biology of multiple cell types associated with tumor growth and metastatic potential [13]. TSP-1 binds to the cell surface receptor $\mathrm{CD} 47$, known also as integrin-associated protein, through the globular carboxy-terminal cell-binding domain. TSP-1/CD47interaction plays important role in tumor progression through the influence on the tumor microenvironment [12,14]. However, the role of TSP-1 in tumor progression is still disputable and there are the studies suggesting opposite effects of TSP-1 depending on the molecular and cellular composition of the microenvironment [15].

TSP-1 is also known as anti-angiogenic factor. TSP-1 may inhibit angiogenesis through direct effects on endothelial cell migration, proliferation, survival and apoptosis [16]. It participates also in regulation of vascular endothelial growth factor (VEGF) bioavailability and activity [15]. TSP-1 directly inhibits VEGF by binding the growth factor and internalizing it via low-density lipoprotein receptor-related protein 1 (LPR1) [17]. TSP-1 is also involved in modulation of tumor immunity [15], including immunosuppressive effect on T cells [11].

BMP-4 is extracellular signaling molecule belonging to the transforming growth factor beta (TGF $\beta$ ) superfamily. BMP-4 is involved in many important processes from bone and cartilage formation through participation in the regulation of cell proliferation and mobility to apoptosis and angiogenesis [18]. BMP-4 also participates in adipogenesis. It stimulates the differentiation of preadipocytes into mature adipocytes [19]. BMP-4 can inhibit cell growth and stimulate migration, invasion and epithelial-mesenchymal transition [18]. BMP4 also contributes to cancer-induced immunosupression. In one study BMP-4 increased the expression of the T cell co-inhibitory receptor ligand PD-L1, leading to CD8+ T cellmediated immunosupression [20]. BMP-4 induces expression of metalloproteinases in neoplastic cells and fibroblasts and in this way could stimulate the matrix degradation capacity of neoplastic cells or activate fibroblasts surrounding tumors to higher expression of matrix metalloproteinases [21]. Genetic variants in BMP-4 in the form of single nucleotide polymorphism (SNP) can be responsible for differences in BMP-4 production and activity.

In vitro study showed that BMP-4 suppressed in paracrine mechanism tumor angiogenesis process via the induction of TSP-1. Effectiveness of BMP-4 in inhibition of the tumor growth was lower in TSP-1 knockdown cancer cells. In this study BMP-4 also reduced VEGF expression in vivo in a TSP-1 dependent manner [22]. This observation confirmed the importance of BMP-4/TSP-1 loop in tumor angiogenesis. It has been found that BMP4nuclear factor of activated T-cells, cytoplasmic 1-TSP-1 axis played important role in lung stem cell differentiation directed by endothelial cells [23].

There is little information regarding the significance of the combination of serum levels of these two proteins, i.e., TSP-1 and BMP-4, and BMP-4 polymorphism in the development and progression of lung cancer. Taking into account the combined influence of BMP-4 and TSP-1 on cancer cells $[22,23]$ we aimed to investigate the serum levels of TSP- 1 and BMP-4 together with SNP of gene coding for BMP-4 (rs1957860) in lung cancer patients in relation to histological type, lymph nodes involvement and the presence of remote metastasis. We 
did not find any previous studies, in which serum levels of TSP-1 and BMP-4, and BMP-4 polymorphism were evaluated together in lung cancer patients.

\section{Material and Methods}

\subsection{Study Groups}

A total of 111 consecutive patients (76 men) with newly diagnosed lung cancer were enrolled in this study. The main inclusion criterion was histopathologically confirmed lung cancer. The patients with any other neoplasm history were excluded from the study. The other exclusion criteria included corticosteroid, biological or immunosuppressive treatment. The mean age of the patients was $65.98 \pm 8.58$ years. Mean body mass index (BMI) was $24.6 \pm 4.6 \mathrm{~kg} / \mathrm{m}^{2}$. There were 102 patients with non-small cell lung cancer (NSCLC), including squamous cell cancer in 36 patients, adenocarcinoma in 22 patients and non-specified (NOS) cancer in 44 patients, and 9 patients with small cell lung cancer (SCLC). Advanced stage of disease was diagnosed in the majority of patients. There were 48 patients in stage IV, 33 patients with stage IIIB, 18 with stage IIIA, 6 with stage II (three-IIA and three-IIB) and 6 with stage I (four-IB, two-IA). The majority of patients were smokers with mean pack-years $30.83 \pm 13.84$ and only four patients were never smokers.

The control group consisted of 61 healthy subjects recruited from Regional Centre of Transfusion Medicine and Blood Bank.

\subsection{ELISA Testing}

Blood samples were collected from fasting subjects in the morning. After centrifugation for $10 \mathrm{~min}$ at $1467 \mathrm{RCF}$ the serum was extracted and stored at $-80{ }^{\circ} \mathrm{C}$. TSP-1 and BMP-4 serum levels were measured using the enzyme-linked immunosorbent assay (ELISA) method. The following kits were used: Human BMP-4 (Thermo Fisher Scientific, Waltham, MA, USA) and Human Thrombospondin-1 (R\&D Systems, Minneapolis, MN, USA). The tests were performed according to the manufacturer's specifications. The ELISA microplate reader from MRXe Dynex Technologies (Chantilly, VA, USA) was used.

\subsection{DNA Extraction and Genes Polymorphism Study}

Genomic DNA was extracted from EDTA-anticoagulated peripheral blood using innuPREP Blood DNA Master Kit (Analytik Jena, Jena, Germany) according to the manufacturer's recommendations and stored at $-20^{\circ} \mathrm{C}$ until required.

Genotyping was performed by the LightSNiP typing assay (TIB-MolBiol, Berlin, Germany) on a LightCycler 480 Real-Time PCR system (Roche Diagnostics, Rotkreuz, Switzerland) following manufacturer's instructions.

\subsection{Statistical Analysis}

Statistical analysis was performed using the CSS Statistica software for Windows (version 5.0). Spearman's $r$ correlation coefficient was used to assess the relationship between two variables and the Mann-Whitney $U$ test was used to compare values between the two groups. Differences between samples were considered significant at $p<0.05$.

\section{Results}

TSP-1 serum levels were significantly lower in the patients with lung cancer than in the controls (TSP-1: 10,109.2 $\pm 9581 \mathrm{ng} / \mathrm{mL}$ vs. $11,415.09 \pm 9781 \mathrm{ng} / \mathrm{mL} p=0.012$ ), Figure 1. In addition, TSP-1 serum levels were lower in patients with advanced lung cancer stages III-IV than in patients with early stages I-II $(9282.07 \pm 4900.78 \mathrm{ng} / \mathrm{mL}$ vs. $16,933.60 \pm 6299.02 \mathrm{ng} / \mathrm{mL} ; p=0.03$ ), (Table 1, Figure 2). The comparison of patients without lymph nodes metastases (N0) and the patients with metastases in any group of lymph nodes (N1) revealed that TSP-1 serum levels were decreased in lung cancer patients with lymph nodes involvement $(10,000.13 \pm 9021.41 \mathrm{ng} / \mathrm{mL}$ vs. $18,497.75 \pm 12,548.25 \mathrm{ng} / \mathrm{mL}$; $p=0.01$ ), (Figure 3). There were no differences in age, BMI or histopathological type between these groups (Table 2). 


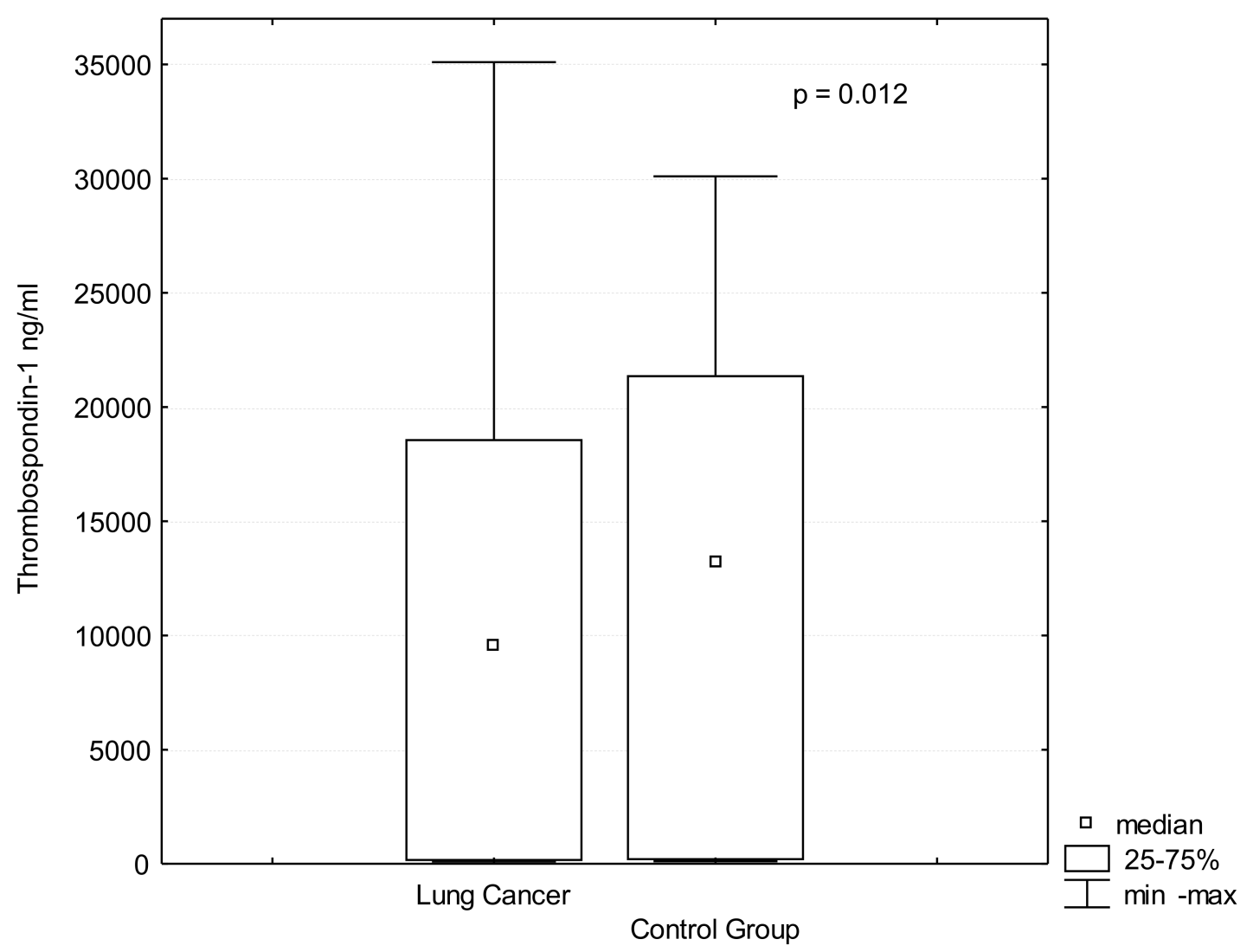

Figure 1. TSP-1 (Thrombospondin-1) serum levels in lung cancer and control group.

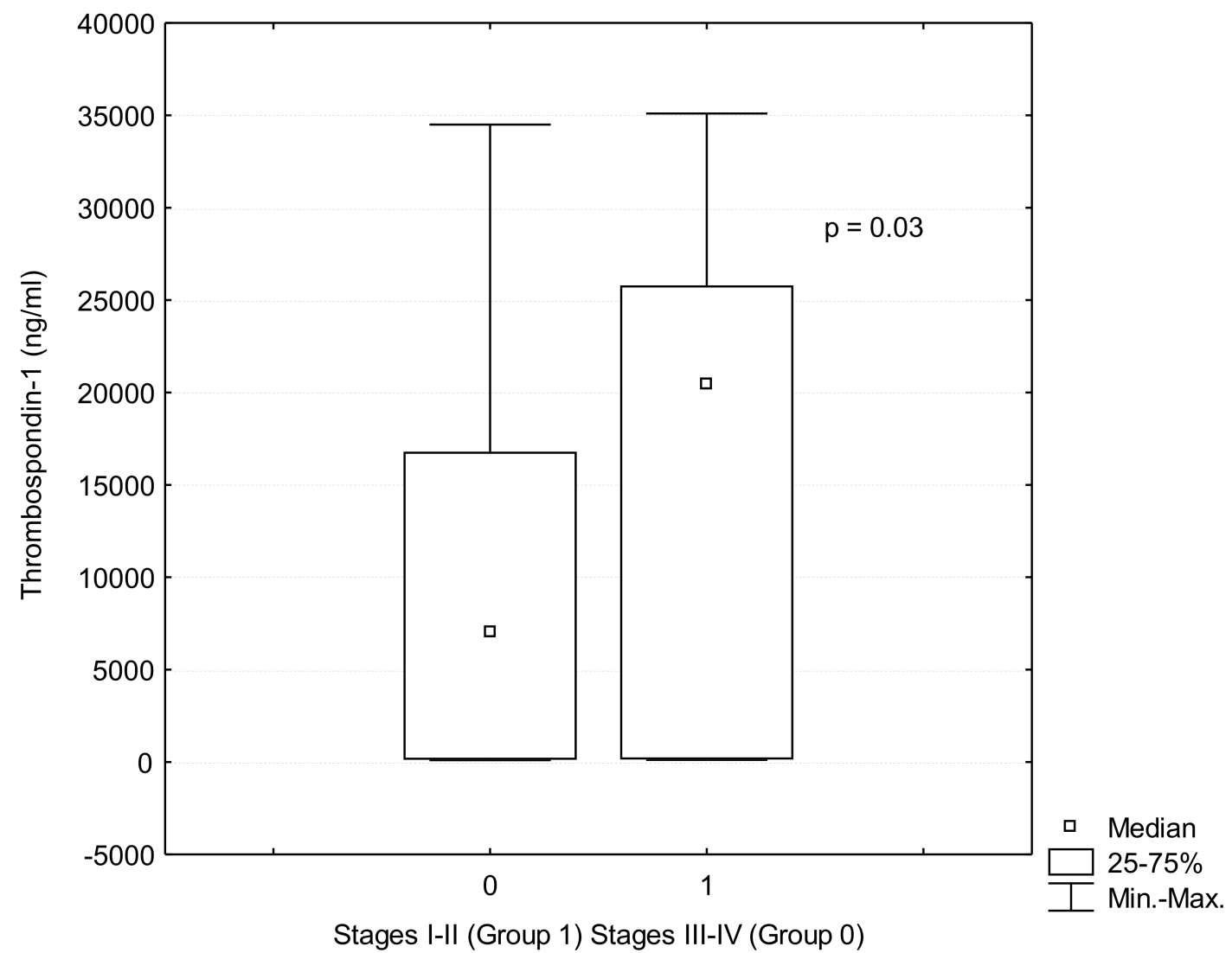

Figure 2. TSP-1 (Thrombospondin-1) serum levels in lung cancer patients in stages I-II (Group 1) and in stages III-IV (Group 0). 


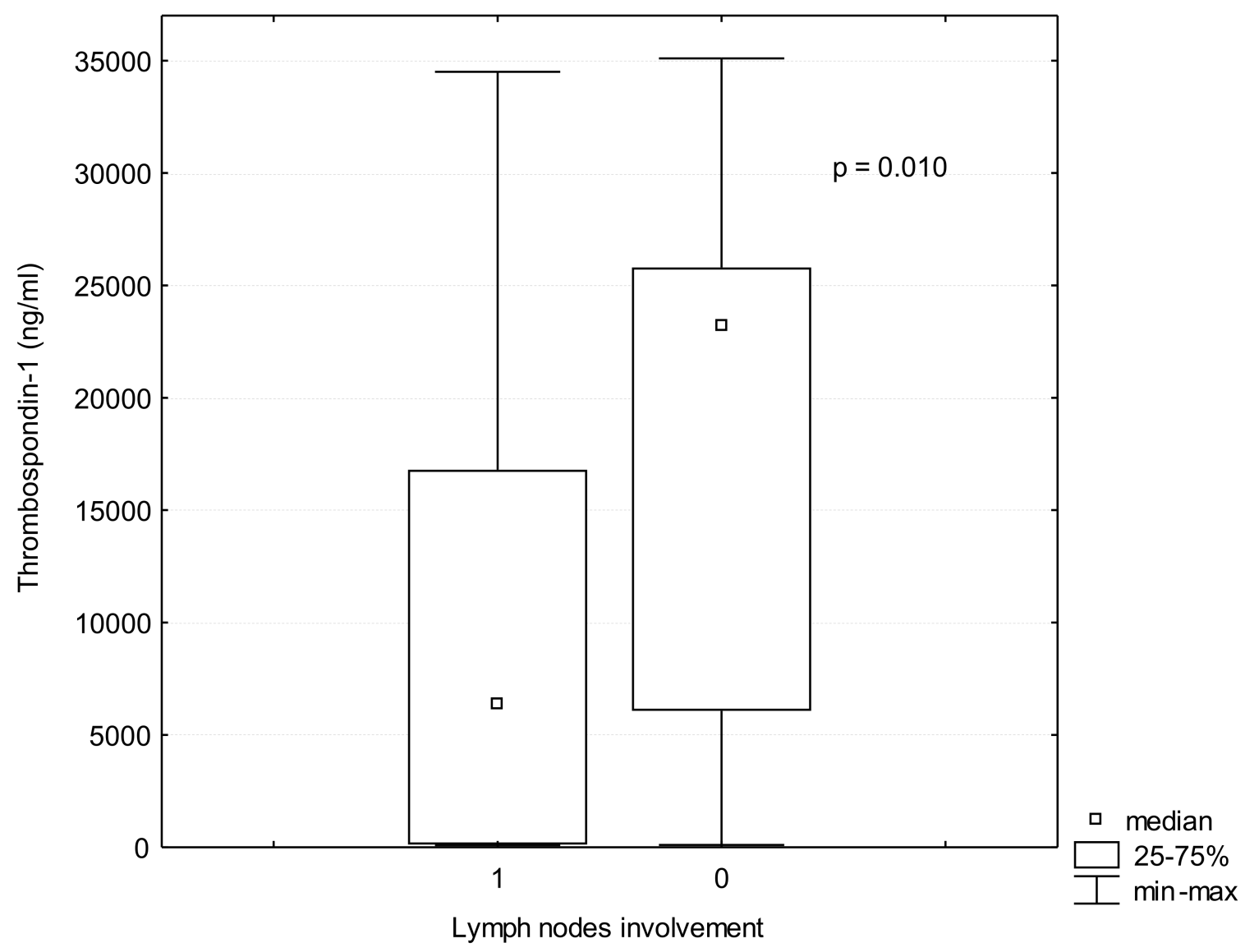

Figure 3. TSP-1 (Thrombospondin-1) serum levels in lung cancer patients with lymph nodes involvement (Group 1) and without lymph nodes involvement (Group 0).

Table 1. The comparison of lung cancer patients in different stages of the disease.

\begin{tabular}{cccccc}
\hline Parameters & Stage I $(\boldsymbol{n}=\mathbf{6})$ & Stage II $(\boldsymbol{n}=\mathbf{6})$ & Stage III $(\boldsymbol{n}=\mathbf{5 1})$ & Stage IV $(\boldsymbol{n}=\mathbf{4 8})$ & $\boldsymbol{p}$ \\
\hline Age $(\mathrm{years})$ & $71.33 \pm 7.71$ & $70.33 \pm 10.32$ & $66.64 \pm 8.71$ & $64.33 \pm 8.49$ & $\mathrm{NS}$ \\
BMI $\left(\mathrm{kg} / \mathrm{m}^{2}\right)$ & $24.87 \pm 4.53$ & $23.66 \pm 2.21$ & $24.75 \pm 5.00$ & $24.48 \pm 4.41$ & $\mathrm{NS}$ \\
TSP-1 $(\mathrm{ng} / \mathrm{mL})$ & $19,355.5 \pm 7914.07$ & $14,510.50 \pm 5000.2$ & $9850.82 \pm 4500.2$ & $9035.18 \pm 5124.9$ & $\mathrm{NS}$ \\
BMP-4 $(\mathrm{pg} / \mathrm{mL})$ & $132.92 \pm 32.92$ & $128.60 \pm 43.06$ & $133.87 \pm 65.38$ & $144.73 \pm 60.55$ & $\mathrm{NS}$ \\
& Stages I and II $(n=12)$ & \multicolumn{2}{c}{ Stages III and IV $(n=99)$} & NS \\
Age $(\mathrm{years})$ & $70.83 \pm 8.70$ & $24.39 \pm 8.42$ & NS \\
BMI $\left(\mathrm{kg} / \mathrm{m}^{2}\right)$ & $24.27 \pm 3.45$ & $24.62 \pm 4.70$ & $p=0.03$ \\
TSP-1 $(\mathrm{ng} / \mathrm{mL})$ & $16,933.60 \pm 6299.02$ & $9282.07 \pm 4900.78$ & $\mathrm{NS}$ \\
BMP-4 $(\mathrm{pg} / \mathrm{mL})$ & $140.96 \pm 55.54$ & $143.29 \pm 63.99$ & \\
\hline
\end{tabular}

TSP-1 (Thrombospondin-1), BMP-4 (bone morphogenetic protein-4), BMI (body mass index).

Table 2. The comparison of lung cancer patients without metastases in lymph nodes with patients with any lymph nodes involvement.

\begin{tabular}{cccc}
\hline Parameters & $\begin{array}{c}\text { Patients without Metastases in } \\
\text { Lymph Nodes }(\boldsymbol{n}=\mathbf{1 2})\end{array}$ & $\begin{array}{c}\text { Patients with Metastases in Any } \\
\text { Lymph Nodes Group }(\boldsymbol{n}=\mathbf{9 9 )}\end{array}$ & $\boldsymbol{p}$ \\
\hline Age (years) & $67.66 \pm 7.59$ & $65.53 \pm 8.62$ & $\mathrm{NS}$ \\
BMI (body mass index) $\left(\mathrm{kg} / \mathrm{m}^{2}\right)$ & $24.99 \pm 4.43$ & $24.53 \pm 4.61$ & $\mathrm{NS}$ \\
TSP-1 $(\mathrm{ng} / \mathrm{mL})$ & $18,497.75 \pm 12,548.25$ & $10,000.13 \pm 9021.41$ & $p=0.01$ \\
BMP-4 $(\mathrm{pg} / \mathrm{mL})$ & $98.56 \pm 62.59$ & $143.82 \pm 62.21$ & $\mathrm{NS}$ \\
\hline
\end{tabular}


BMP-4 serum levels were significantly lower in the patients with lung cancer than in the control group $(138.35 \pm 62.59 \mathrm{pg} / \mathrm{mL}$ vs. $226.68 \pm 135.86 \mathrm{pg} / \mathrm{mL}, p<0.001)$, (Figure 4). In the case of BMP-4 there were no differences in BMP-4 levels related to lung cancer stages (Table 1) or lymph nodes involvement (Table 2).

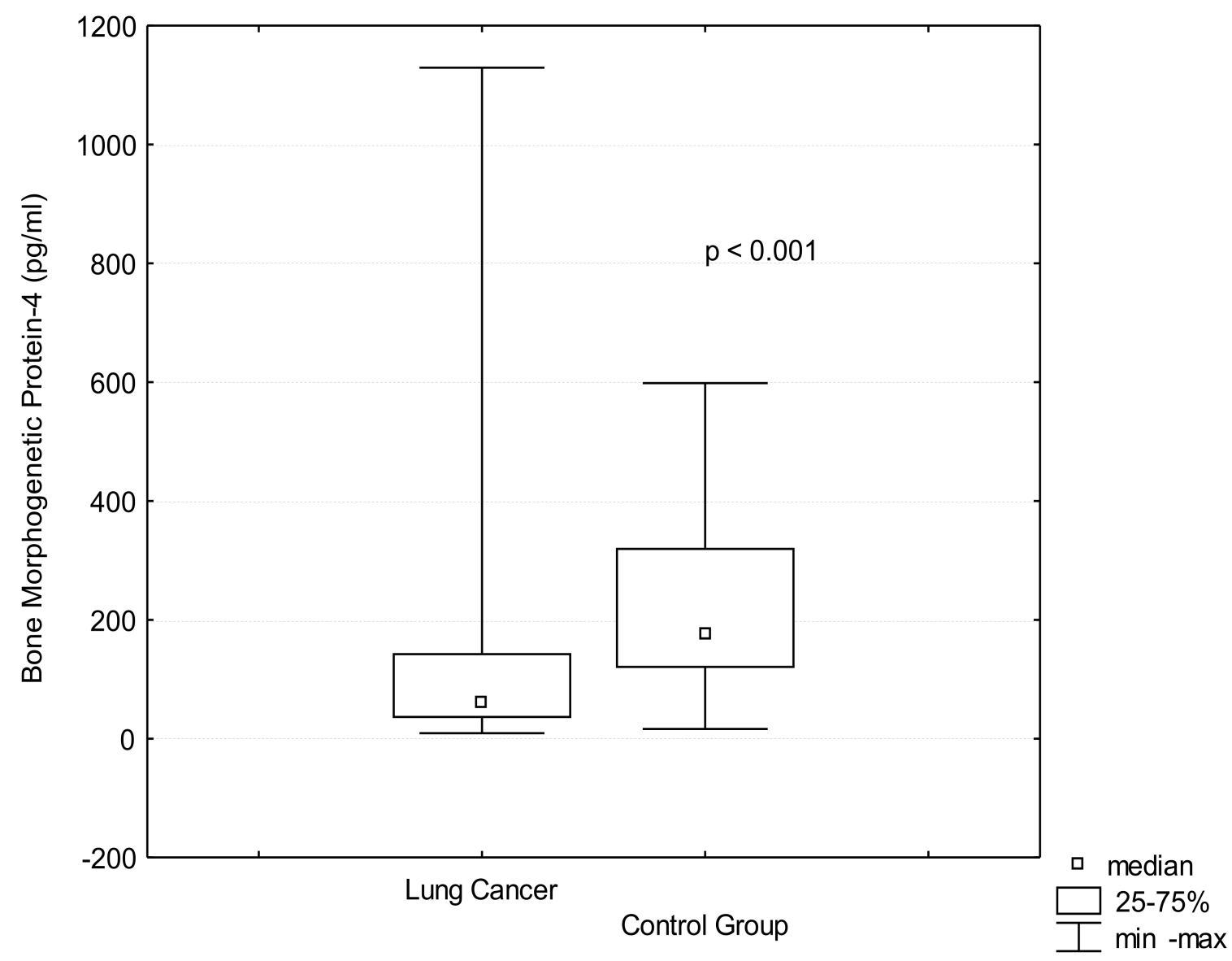

Figure 4. BMP-4 serum levels in lung cancer and control group. BMP-4 (bone morphogenetic protein-4).

There were no differences in BMP-4 or TSP-1 levels in NSCLC as compared with SCLC patients. There were no differences in BMP-4 or TSP-1 serum levels in different histological subtypes of NSCLC, especially between the two most common histopathological types of NSCLC: adenocarcinoma and squamous cell lung cancer patients. Differences neither in TSP-1 levels $(12,414.18 \pm 11,650.28 \mathrm{ng} / \mathrm{mL}$ vs. $10,683.84 \pm 10,534.9 \mathrm{ng} / \mathrm{mL} p=0.712)$ nor in BMP-4 (103.60 $\pm 60.55 \mathrm{pg} / \mathrm{mL}$ vs. $166,70 \pm 62.59 \mathrm{pg} / \mathrm{mL} p=0.655)$ were found (Table 3).

Table 3. TSP-1 and BMP-4 serum levels in different histopathological types of lung cancer.

\begin{tabular}{cccc}
\hline Parameters & NSCLC $(\boldsymbol{n}=\mathbf{1 0 2})$ & SCLC $(\boldsymbol{n}=\mathbf{9 )}$ & $\boldsymbol{p}$ \\
\hline TSP-1 $(\mathrm{ng} / \mathrm{mL})$ & $10,093.04 \pm 10,716.06$ & $10,292.44 \pm 10,491.16$ & $\mathrm{NS}$ \\
BMP-4 $(\mathrm{pg} / \mathrm{mL})$ & $140.67 \pm 60.55$ & $114.23 \pm 82.96$ & $\mathrm{NS}$ \\
Squamous Cell Lung Cancer $(n=36)$ & \multicolumn{2}{c}{ Adenocarcinoma $(n=22)$} \\
TSP-1 $(\mathrm{ng} / \mathrm{mL})$ & $10,683.84 \pm 10,534.9$ & $12,414.18 \pm 11,650.28$ & $\mathrm{NS}$ \\
BMP-4 $(\mathrm{pg} / \mathrm{mL})$ & $166.70 \pm 62.59$ & $103.60 \pm 60.55$ & $\mathrm{NS}$ \\
\hline
\end{tabular}

TSP-1 (Thrombospondin-1), BMP-4 (bone morphogenetic protein-4), NSCLC (non small cell lung cancer), SCLC (small cell lung cancer).

There was no correlation between TSP-1 and BMP-4 serum levels. There were no differences in BMP-4 and TSP-1 serum levels related to BMP-4 gene polymorphisms (Table 4). 
Table 4. TSP-1 and BMP-4 serum levels and BMP-4 polymorphism.

\begin{tabular}{ccccc}
\hline Parameters & \multicolumn{3}{c}{ rs1957860 } & p \\
\cline { 2 - 4 } & $\mathrm{CT}(\boldsymbol{n}=\mathbf{5 2})$ & $\mathrm{TT}(\boldsymbol{n}=\mathbf{3 6})$ & $\mathrm{CC}(\boldsymbol{n}=\mathbf{2 5 )}$ & \\
\hline $\begin{array}{c}\text { BMP-4 serum levels } \\
\text { (pg/mL) }\end{array}$ & $137.82 \pm 62.21$ & $154.14 \pm 76.12$ & $140.81 \pm 57.25$ & $\mathrm{NS}$ \\
$\begin{array}{c}\text { TSP-1 serum levels } \\
(\mathrm{ng} / \mathrm{mL})\end{array}$ & $11,982.26 \pm 10,091.37$ & $10,672.13 \pm 9298.92$ & $13,412.76 \pm 12,421.90$ & $\mathrm{NS}$ \\
\hline
\end{tabular}

TSP-1 (Thrombospondin-1), BMP-4 (bone morphogenetic protein-4), CT (cytosine, thymine), TT (thymine, thymine), CC (cytosine, cytosine).

\section{Discussion}

The main importance of our study is finding of decreased serum levels of TSP- 1 and BMP-4 in lung cancer patients. Moreover, we showed that TSP-1 serum levels were lower in patients with advanced lung cancer stages and lymph nodes involvement. In the previous studies BMP-4 and TSP-1 in lung cancer patients were mostly studied separately [24-27].

Our results showing decreased serum levels of TSP-1 in lung cancer patients, are in agreement with some previous studies [24-26]. The importance of TSP-1 in lung cancer emphasized the studies in which many biomarkers were evaluated at the same time. In one study 70 cancer-related proteins were measured and the authors identified a panel of 10 serum biomarkers, including TSP-1, which distinguished lung cancer patients from the controls [28]. Newest study demonstrated that TSP-1 together with two other biomarkers: brain angiogenesis inhibitor 1 and E-Cadherin had higher sensitivity and specificity than classical biomarkers in early diagnosis of lung cancer [29].

We did not find any previous study in which lower TSP-1 serum correlated with lymph nodes involvement. Our findings could indicate the prognostic value of TSP-1. In primary resected NSCLC $(n=171)$ TSP-1 levels inversely correlated with survival [25]. In this study for each 10 units of increment of TSP-1 the risk of death decreased by $85 \%$ and the multivariate analysis confirmed that decreased TSP-1 was independent prognostic factor of overall survival. However, there was no correlation between TSP-1 serum levels and distant metastasis free survival. In another study a set of angiogenesis, inflammation and coagulation markers was analyzed in patients treated for advanced NSCLC. Only lower TSP-1 serum levels and higher VEGF were unfavorable prognostic factors in the examined group [26]. Moreover, previous immunohistochemical studies revealed that reduced expression of TSP-1 in resected tumor tissue was associated with shorter 5-year survival [30]. Low TSP-1 mRNA expression was also connected with poorer prognosis in advanced NSCLC [31]. Even though BMP-4 seems to be promising molecule in lung cancer diagnosis and monitoring, the majority of studies based on tissue expression or genetic examinations. We were not able to find any previous publication in which BMP-4 serum levels were examined in lung cancer patients.

Higher expression of BMP-4 mRNAs (2.3 times) in lung cancer than in normal lung tissue has been reported [32]. Newest in vitro studies confirmed the role of BMP-4 in lung cancer progression. In the BMP-4 knockdown lung cancer cell lines inhibition of cell growth, migration, invasion and metastases formation was observed [33].

Genetic polymorphisms of BMP-4 and BMP-4 tissue expression may serve as potential predictor of the chemotherapy response and prognosis. In the group of 938 patients with advanced NSCLC (stages III and IV) the 6007CC genotype variant of BMP-4 was related to higher chance of platinum-based chemotherapy response, but in the patients with high BMP-4 protein expression chemotherapy resistance was observed more commonly [27].

The newest experimental studies revealed overexpression of BMP-4 in the NSCLC cells with acquired EGFR-tyrosine kinase inhibitor resistance. In addition, the authors indicated that BMP-4 mechanism of action was associated with activation of neoplastic cells energy metabolism [34]. Moreover, in vitro studies indicated that BMP-4 could be potential therapeutic target in the treatment of lung cancer patients [35]. 
Experience in the other neoplastic diseases indicate the BMP-4 importance. In breast cancer BMP-4 promotes the migration and invasion of cancer cells, at least in part by up-regulating the expressions of matrix metalloproteinase- 1 and chemokine receptor type 4 [36].

Studies in non-neoplastic diseases indicate on the relationship between BMP-4 and obesity with metabolic syndrome. Higher BMP-4 serum levels in obese patients, positively correlating with BMI, waist circumference, waist-to-hip ratio and fasting insulin have been found [37]. Weight lost associated with gastric bypass led to significant decrease of BMP-4 [38].

It is not easy to explain, why the decreased levels of these two markers: TSP- 1 and BMP-4 might promote tumor development, because the role in cancer progression of these two analyzed markers remains unclear. A number of studies confirm anti-tumor functions of TSP-1 and BMP-4 [13,17,39-41].

In the case of TSP-1, as mentioned in introduction, majority of available literature indicate the role of tumor microenvironment [13], especially TSP-1/CD47 interaction seems to play key role $[12,14]$. In addition, in premalignant lung tumors TSP-1 participates in suppression of Kras-induced tumorigenesis [42]. TSP-1 is also identified as neovascularization blocker, which could slow down malignant tumor growth [17]. That is why some authors consider TSP-1 to be the anti-metastatic protein [39].

BMP-4 is involved in inhibition of metalloproteinase-9, which is locally produced by tumor and through the degradation of the extracellular matrix, increased proliferation and invasiveness of tumor [43]. In addition, BMP-4 decreased the tumorigenic potential of human brain-initiating cells [40]. In animal model of breast cancer, it has been shown that BMP4 blocked metastasis formation through the activation of canonical BMP4-SMAD7 signaling, what might suggest that targeting the BMP4-SMAD7 signaling axis presents a novel therapeutic strategy [41].

Numerous data indicate that SNP variants could be implicated in the development of various cancer types [44]. Genetic variants of BMP-4 could lead to the changes in the local production of BMP-4 or in its effectiveness [27]. In lung cancer patients BMP-4 genetic variants influenced platinum-based chemotherapy response and prognosis [45].

Table 5 shows summarization of the previous laboratory and clinical studies indicating the role of TSP-1 and BMP-4 in the lung cancer development. Our study adds to the existing knowledge the findings that not only both TSP-1 and BMP-4 levels as measured by ELISA in the serum of the patients are decreased in lung cancer, but also that TSP- 1 is associated with more advanced lung cancer stages and lymph nodes involvement. Even though our results appeared negative the correlation between TSP- 1 and BMP-4 serum levels, as well as the possible association between BMP-4 gene polymorphism and serum levels of this biomarker have not been studied before.

Table 5. TSP-1 and BMP-4 studies in lung cancer patients.

\begin{tabular}{cccc}
\hline Biomarker & Material/Method & Results/Conclusion & Author \\
\hline TSP-1 & $\begin{array}{c}\text { Plasma of lung cancer } \\
\text { patient/ELISA }\end{array}$ & $\begin{array}{c}\text { Down-regulation of expression of TSP-1/potential } \\
\text { usefulness in lung cancer diagnosis }\end{array}$ & Zhang L. et al., 2019 [29] \\
TSP-1 & $\begin{array}{c}\text { Lung metastatic tumors/gene } \\
\text { expression signature }\end{array}$ & $\begin{array}{c}\text { Up-regulation in lung metastes of } \\
\text { osteosarcoma/contribution of TSP-1 to } \\
\text { lung metastases }\end{array}$ & Hu C. et al., 2017 [46] \\
TSP-1 & $\begin{array}{c}\text { Lung cancer patients } \\
\text { undergoing surgical } \\
\text { treatment/ELISA }\end{array}$ & TSP-1 is inversely correlated with survival & Rouanne M. et al., \\
TSP-1 & $\begin{array}{c}\text { Microarray databases/ } \\
\text { systematic-analysis }\end{array}$ & $\begin{array}{c}\text { Underexpression in lung cancer/TSP-1 as tumor } \\
\text { suppressor in lung adenocarcinoma }\end{array}$ & 2016 [25] \\
& & Weng T.Y. et al., 2016 [47] & \\
\hline
\end{tabular}


Table 5. Cont.

\begin{tabular}{|c|c|c|c|}
\hline Biomarker & Material/Method & Results/Conclusion & Author \\
\hline TSP-1 & $\begin{array}{l}\text { Lung cancer speci- } \\
\text { mens/immunochemistry }\end{array}$ & $\begin{array}{l}\text { Lower expression of TSP-1 in late than in early stage } \\
\text { of lung cancer/high expression of TSP-1 may inhibit } \\
\text { tumor development }\end{array}$ & Chen Z.J. et al., 2009 [48] \\
\hline TSP-1 & $\begin{array}{l}\text { Plasma of advanced lung } \\
\text { cancer patients/ELISA }\end{array}$ & $\begin{array}{l}\text { Decreased TSP-1 levels than in healthy } \\
\text { controls/TSP-1 may increase tumor angiogenesis }\end{array}$ & $\begin{array}{l}\text { Dudek A.Z. and } \\
\text { Mahaseth H. } 2005 \text { [24] }\end{array}$ \\
\hline TSP-1 & Different tumors/review & $\begin{array}{l}\text { TSP-1 suppresses tumor progression and } \\
\text { inhibits angiogenesis }\end{array}$ & Lawler J. 2002 [49] \\
\hline TSP-1 & $\begin{array}{l}\text { Resected lung cancer speci- } \\
\text { mens/immunochemistry }\end{array}$ & $\begin{array}{c}\text { Reduced expression of TSP-1 is associated with } \\
\text { decreased 5-year survival/usefulness of TSP-1 as } \\
\text { prognostic marker }\end{array}$ & $\begin{array}{l}\text { Yamaguchi M. et al., } \\
2002[30]\end{array}$ \\
\hline BMP-4 & $\begin{array}{l}\text { Lung cancer specimens / qPCR } \\
\text { and immunochemistry; } \\
\text { survival of the patients }\end{array}$ & $\begin{array}{c}\text { Increased BMP-4 levels in advanced stages of lung } \\
\text { cancer and in the patients with shortened survival } \\
\text { / usefulness of BMP-4 as prognostic factor }\end{array}$ & Ju F.J. et al., 2019 [50] \\
\hline BMP-4 & $\begin{array}{l}\text { Lung cancer specimens before } \\
\text { chemotherapy/western } \\
\text { blot assay }\end{array}$ & $\begin{array}{c}\text { Higher BMP-4 expression increases risk of resistance } \\
\text { to chemotherapy/the usefulness of BMP-4 tissue } \\
\text { expression as a prognostic factor }\end{array}$ & Xian S. et al., 2014 [27] \\
\hline
\end{tabular}

TSP-1 (Thrombospondin-1), BMP-4 (bone morphogenetic protein-4), ELISA (enzyme linked immunosorbent assay), PCR (polymerase chain reaction).

\section{Conclusions}

The study confirms a role of decreased serum expression of TSP-1 and BMP-4 as the markers of lung cancer, with the lowest TSP-1 concentrations associated with more advanced lung cancer stages and with lymph nodes involvement.

Author Contributions: Conceptualization, M.K., A.B. and M.C.-M.; methodology, M.K., M.C.-M. and K.B.-K.; software, M.K.; validation, M.K. and A.B.; formal analysis, M.K. and A.B.; investigation, M.K., T.D. and A.B.; resources, M.K. and A.B.; data curation, M.K.; writing-original draft preparation, M.K.; writing-review and editing, M.K and A.B.; visualization, M.K.; supervision, A.B.; project administration, M.K. and A.B.; funding acquisition, M.K. and A.B. All authors have read and agreed to the published version of the manuscript.

Funding: The research received no external funding.

Institutional Review Board Statement: The study was conducted according to the guidelines of the Declaration of Helsinki, and approved by the Institutional Ethics Committee of Wroclaw Medical University (Protocol code No. 678/2015).

Informed Consent Statement: Informed consent was obtained from all subjects involved in the study.

Data Availability Statement: We exclude this statement.

Acknowledgments: The study was a part of the Wroclaw Medical University Project No. 935 and SUB.C110.21.047.

Conflicts of Interest: The authors declare no conflict of interest.

\section{References}

1. Bade, B.C.; Dela Cruz, C.S. Lung cancer 2020: Epidemiology, etiology, and prevention. Clin. Chest Med. 2020, 41, 1-24. [CrossRef] [PubMed]

2. Didkowska, J.; Wojciechowska, U.; Manczuk, M.; Łobaszewski, J. Lung cancer epidemiology: Contemporary and future challenges worldwide. Ann. Transl. Med. 2016, 4, 150. [CrossRef] [PubMed]

3. Allemani, C.; Matsuda, T.; Di Carlo, V.; Harewood, R.; Matz, M.; Nikšić, M.; Bonaventure, A.; Valkov, M.; Johnson, C.J.; Estève, J.; et al. CONCORD Working Group. Global surveillance of trends in cancer survival 2000-14 (CONCORD-3): Analysis of individual records for 37513025 patients diagnosed with one of 18 cancers from 322 population-based registries in 71 countries. Lancet 2018, 391, 1023-1075. [CrossRef]

4. Barbareschi, M.; Barberis, M.; Buttitta, F.; Doglioni, C.; Fiorentino, M.; Fontanini, G.; Franco, R.; Marchetti, A.; Rossi, G.; Troncone, G. Predictive markers in lung cancer: A few hints for the practicing pathologist. Pathologica 2018, 110, 29-38.

5. Shea, M.; Costa, D.; Rangachari, D. Management of advanced non-small cell lung cancers with known mutations or rearrangements: Latest evidence and treatment approaches. Ther. Adv. Respir. Dis. 2015, 10, 113-129. [CrossRef] [PubMed] 
6. Korpanty, G.J.; Graham, D.M.; Vincent, M.D.; Leighl, N.B. Biomarkers that currently affect clinical practice in lung cancer: EGFR, ALK, MET, ROS-1, and KRAS. Front. Oncol. 2014, 4, 204. [CrossRef]

7. Adams, J.C.; Lawler, J. The thrombospondins. Cold Spring Harb. Perspect. Biol. 2011, 3, a009712. [CrossRef]

8. Natale, G.; Bocci, G. Does metronomic chemotherapy induce tumor angiogenic dormancy? A review of available preclinical and clinical data. Cancer Lett. 2018, 432, 28-37. [CrossRef]

9. Bentley, A.A.; Adams, J.C. The evolution of thrombospondins and their ligand-binding activities. Mol. Biol. Evol. 2010, 27, 2187-2197. [CrossRef]

10. Murphy-Ullrich, J.E.; Iozzo, R.V. Thrombospondins in physiology and disease: New tricks for old dogs. Matrix Biol. 2012, 31, 152-154. [CrossRef]

11. Ramchandani, D.; Mittal, V. Thrombospondin. In Tumor Microenvironment; Springer: Cham, Switzerland, 2020; pp. 133-147. [CrossRef]

12. Sick, E.; Jeanne, A.; Schneider, C.; Dedieu, S.; Takeda, K.; Martiny, L. CD47 update: A multifaceted actor in the tumour microenvironment of potential therapeutic interest. Br. J. Pharmacol. 2012, 167, 1415-1430. [CrossRef]

13. Kaur, S.; Bronson, S.; Pal-Nath, D.; Miller, T.; Soto-Pantoja, D.; Roberts, D. Functions of thrombospondin-1 in the tumor microenvironment. Int. J. Mol. Sci. 2021, 22, 4570. [CrossRef]

14. Gao, A.-G.; Lindberg, F.P.; Finn, M.B.; Blystone, S.D.; Brown, E.J.; Frazier, W.A. Integrin-associated protein is a receptor for the C-terminal domain of thrombospondin. J. Biol. Chem. 1996, 271, 21-24. [CrossRef]

15. Huang, W.-T.; Chong, I.-W.; Chen, H.-L.; Li, C.-Y.; Hsieh, C.-C.; Kuo, H.-F.; Chang, C.-Y.; Chen, Y.-H.; Liu, Y.-P.; Lu, C.-Y.; et al. Pigment epithelium-derived factor inhibits lung cancer migration and invasion by upregulating exosomal thrombospondin 1. Cancer Lett. 2018, 442, 287-298. [CrossRef] [PubMed]

16. Lawler, P.; Lawler, J. Molecular basis for the regulation of angiogenesis by thrombospondin-1 and -2. Cold Spring Harb. Perspect. Med. 2012, 2, a006627. [CrossRef]

17. Greenaway, J.; Lawler, J.; Moorehead, R.; Bornstein, P.; LaMarre, J.; Petrik, J. Thrombospondin-1 inhibits VEGF levels in the ovary directly by binding and internalization via the low density lipoprotein receptor-related protein-1 (LRP-1). J. Cell. Physiol. 2006, 210, 807-818. [CrossRef]

18. Kallioniemi, A. Bone morphogenetic protein 4-A fascinating regulator of cancer cell behavior. Cancer Genet. 2012, 205, 267-277. [CrossRef]

19. Bowers, R.R.; Lane, M.D. A role for bone morphogenetic protein-4 in adipocyte development. Cell Cycle 2007, 6, 385-389. [CrossRef] [PubMed]

20. Chen, L.; Yi, X.; Goswami, S.; Ahn, Y.-H.; Roybal, J.D.; Yang, Y.; Diao, L.; Peng, D.; Peng, D.; Fradette, J.; et al. Growth and metastasis of lung adenocarcinoma is potentiated by BMP4-mediated immunosuppression. OncoImmunology 2016, 5, e1234570. [CrossRef] [PubMed]

21. Rothhammer, T.; Braig, S.; Bosserhoff, A. Bone morphogenetic proteins induce expression of metalloproteinases in melanoma cells and fibroblasts. Eur. J. Cancer 2008, 44, 2526-2534. [CrossRef] [PubMed]

22. Tsuchida, R.; Osawa, T.; Wang, F.; Nishii, R.; Das, B.; Muramatsu, M.; Takahashi, T.; Inoue, T.; Wada, Y.; Minami, T.; et al. BMP4/Thrombospondin-1 loop paracrinically inhibits tumor angiogenesis and suppresses the growth of solid tumors. Oncogene 2013, 33, 3803-3811. [CrossRef] [PubMed]

23. Lee, J.-H.; Bhang, D.H.; Beede, A.; Huang, T.L.; Stripp, B.R.; Bloch, K.D.; Wagers, A.J.; Tseng, Y.-H.; Ryeom, S.; Kim, C.F. Lung stem cell differentiation in mice directed by endothelial cells via a BMP4-NFATc1-thrombospondin-1 axis. Cell 2014, 156, 440-455. [CrossRef]

24. Dudek, A.Z.; Mahaseth, H. Circulating angiogenic cytokines in patients with advanced non-small cell lung cancer: Correlation with treatment response and survival. Cancer Investig. 2005, 23, 193-200. [CrossRef]

25. Rouanne, M.; Adam, J.; Goubar, A.; Robin, A.; Ohana, C.; Louvet, E.; Cormier, J.; Mercier, O.; Dorfmüller, P.; Fattal, S.; et al. Osteopontin and thrombospondin-1 play opposite roles in promoting tumor aggressiveness of primary resected non-small cell lung cancer. BMC Cancer 2016, 16, 483. [CrossRef]

26. Fleitas, T.; Martínez-Sales, V.; Vila, V.; Reganon, E.; Mesado, D.; Martin, M.; Gómez-Codina, J.; Montalar, J.; Reynes, G. VEGF and TSP1 levels correlate with prognosis in advanced non-small cell lung cancer. Clin. Transl. Oncol. 2013, 15, 897-902. [CrossRef] [PubMed]

27. Xian, S.; Jilu, L.; Zhennan, T.; Yang, Z.; Yang, H.; Jingshu, G.; Songbin, F. BMP-4 genetic variants and protein expression are associated with platinum-based chemotherapy response and prognosis in NSCLC. BioMed Res. Int. 2014, 2014, 801640. [CrossRef]

28. Bigbee, W.L.; Gopalakrishnan, V.; Weissfeld, J.L.; Wilson, D.O.; Dacic, S.; Lokshin, A.E.; Siegfried, J.M. A multiplexed serum biomarker immunoassay panel discriminates clinical lung cancer patients from high-risk individuals found to be cancer-free by CT screening. J. Thorac. Oncol. 2012, 7, 698-708. [CrossRef] [PubMed]

29. Zhang, L.; Pu, D.; Liu, D.; Wang, Y.; Luo, W.; Tang, H.; Huang, Y.; Li, W. Identification and validation of novel circulating biomarkers for early diagnosis of lung cancer. Lung Cancer 2019, 135, 130-137. [CrossRef]

30. Yamaguchi, M.; Sugio, K.; Ondo, K.; Yano, T.; Sugimachi, K. Reduced expression of thrombospondin-1 correlates with a poor prognosis in patients with non-small cell lung cancer. Lung Cancer 2002, 36, 143-150. [CrossRef] 
31. Papadaki, C.; Mavroudis, D.; Trypaki, M.; Koutsopoulos, A.; Stathopoulos, E.; Hatzidaki, D.; Tsakalaki, E.; Georgoulias, V.; Souglakos, J. Tumoral expression of TXR1 and TSP1 predicts overall survival of patients with lung adenocarcinoma treated with first-line docetaxel-gemcitabine regimen. Clin. Cancer Res. 2009, 15, 3827-3833. [CrossRef]

32. Bieniasz, M.; Oszajca, K.; Eusebio, M.; Kordiak, J.; Bartkowiak, J.; Szemraj, J. The positive correlation between gene expression of the two angiogenic factors: VEGF and BMP-2 in lung cancer patients. Lung Cancer 2009, 66, 319-326. [CrossRef] [PubMed]

33. Kim, J.S.; Kurie, J.M.; Ahn, Y.-H. BMP4 depletion by miR-200 inhibits tumorigenesis and metastasis of lung adenocarcinoma cells. Mol. Cancer 2015, 14, 1-11. [CrossRef] [PubMed]

34. Bach, D.-H.; Luu, T.-T.; Kim, D.; An, Y.J.; Park, S.; Park, H.J.; Lee, S.K. BMP4 Upregulation is associated with acquired drug resistance and fatty acid metabolism in EGFR-mutant non-small-cell lung cancer cells. Mol. Ther. Nucleic Acids 2018, 12, 817-828. [CrossRef] [PubMed]

35. Bao, L.; Lv, L.; Feng, J.; Chen, Y.; Wang, X.; Han, S.; Zhao, H. MiR-876-5p suppresses epithelial-mesenchymal transition of lung cancer by directly down-regulating bone morphogenetic protein 4. J. Biosci. 2017, 42, 671-681. [CrossRef] [PubMed]

36. Guo, D.; Huang, J.; Gong, J. Bone morphogenetic protein 4 (BMP4) is required for migration and invasion of breast cancer. Mol. Cell. Biochem. 2011, 363, 179-190. [CrossRef]

37. Son, J.W.; Kim, M.-K.; Park, Y.-M.; Baek, K.-H.; Yoo, S.J.; Song, K.-H.; Son, H.S.; Yoon, K.-H.; Lee, W.C.; Cha, B.-Y.; et al. Association of serum bone morphogenetic protein 4 levels with obesity and metabolic syndrome in non-diabetic individuals. Endocr. J. 2011, 58, 39-46. [CrossRef]

38. Kim, M.K.; Jang, E.-H.; Hong, O.-K.; Chun, H.-J.; Yoo, S.-J.; Baek, K.-H.; Kim, W.; Kim, E.K.; Song, K.-H.; Kwon, H.-S. Changes in serum levels of bone morphogenic protein 4 and inflammatory cytokines after bariatric surgery in severely obese korean patients with type 2 diabetes. Int. J. Endocrinol. 2013, 2013, 1-5. [CrossRef]

39. Manni, A.; Rager, T.; Kimball, S.R.; Jefferson, L.S.; Washington, S.; Hu, X.; Verderame, M.F. Effects of alpha-difluoromethylornithine on thrombospondin-1 production by human breast cancer cells. Int. J. Oncol. 2007, 31, 1187-1191. [PubMed]

40. Piccirillo, S.G.M.; Reynolds, B.A.; Zanetti, N.; Lamorte, G.; Binda, E.; Broggi, G.; Brem, H.; Olivi, A.; DiMeco, F.; Vescovi, A.L. Bone morphogenetic proteins inhibit the tumorigenic potential of human brain tumour-initiating cells. Nature 2006, 444, 761-765. [CrossRef]

41. Eckhardt, B.L.; Cao, Y.; Redfern, A.D.; Chi, L.H.; Burrows, A.D.; Roslan, S.; Sloan, E.K.; Parker, B.S.; Loi, S.; Ueno, N.T.; et al. Activation of canonical BMP4-SMAD7 signaling suppresses breast cancer metastasis. Cancer Res. 2020, 80, 1304-1315. [CrossRef] [PubMed]

42. Baek, K.-H.; Bhang, D.; Zaslavsky, A.; Wang, L.-C.; Vachani, A.; Kim, C.F.; Albelda, S.M.; Evan, G.I.; Ryeom, S. Thrombospondin-1 mediates oncogenic Ras-induced senescence in premalignant lung tumors. J. Clin. Investig. 2013, 123, 4375-4389. [CrossRef]

43. Laulan, N.B.; St-Pierre, Y. Bone morphogenetic protein 4 (BMP-4) and epidermal growth factor (EGF) inhibit metalloproteinase-9 (MMP-9) expression in cancer cells. Oncoscience 2014, 2, 309-316. [CrossRef]

44. Deng, N.; Zhou, H.; Fan, H.; Yuan, Y. Single nucleotide polymorphisms and cancer susceptibility. Oncotarget 2017, 8, 110635110649. [CrossRef]

45. Lin, J.-Y.; Chen, Y.-J.; Huang, Y.-L.; Tang, G.-P.; Zhang, L.; Deng, B.; Li, M.; Ma, H.; Luan, R.-S. Association of bone morphogenetic protein 4 gene polymorphisms with nonsyndromic cleft lip with or without cleft palate in Chinese children. DNA Cell Biol. 2008, 27, 601-605. [CrossRef] [PubMed]

46. Hu, C.; Wen, J.; Gong, L.; Chen, X.; Wang, J.; Hu, F.; Zhou, Q.; Liang, J.; Wei, L.; Shen, Y.; et al. Thrombospondin-1 promotes cell migration, invasion and lung metastasis of osteosarcoma through FAK dependent pathway. Oncotarget 2017, 26, 75881-75892. [CrossRef] [PubMed]

47. Weng, T.-Y.; Wang, C.-Y.; Hung, Y.-H.; Chen, W.-C.; Chen, Y.-L.; Lai, M.-D. Differential expression pattern of THBS1 and THBS2 in lung cancer: Clinical outcome and a systematic-analysis of microarray databases. PLoS ONE 2016, 11, e0161007. [CrossRef]

48. Chen, Z.; Le, H.; Zhang, Y.; Qian, L.; Li, W. Microvessel density and expression of thrombospondin-1 in non-small cell lung cancer and their correlation with clinicopathological features. J. Int. Med Res. 2009, 37, 551-556. [CrossRef]

49. Lawler, J. Thrombospondin-1 as an endogenous inhibitor of angiogenesis and tumor growth. J. Cell. Mol. Med. 2002, 6, 1-12. [CrossRef]

50. Ju, F.-J.; Meng, F.-Q.; Hu, H.-L.; Liu, J. Association between BMP4 expression and pathology, CT characteristics and prognosis of non-small cell lung cancer. Eur. Rev. Med. Pharm. Sci. 2019, 23, 5787-5794. 